\title{
GAZDASÁGFEJLESZTÉSI LEHETŐSÉGEK A JÓL MŰKÖDŐ TELEPÜLÉSEKEN ${ }^{1}$ ECONOMIC DEVELOPMENT OPPORTUNITIES IN WELL-FUNCTIONING SETTLEMENTS
}

\section{Tóth Tamás}

\author{
egyetemi tanár \\ Szent István Egyetem, Gazdaság és Társadalomtudományi Kar \\ E-mail: toth.tamas.argi@gtk.szie.hu
}

\section{Összefoglalás}

Ezt a témát azért választottam, hogy rávilágítsak a települések gazdaságfejlesztési feladatainak fontosságára, a gazdaság- és területi politikában az önkormányzatok, azon belül pedig a településeket irányító vezetők meghatározó szerepére. A települések fejlesztésében a vezetés gondolkodás módja és elképzeléseik igen meghatározó tényezők. Napjainkban a településfejlesztés és a regionális gazdaságfejlesztés olyan kulcsfontosságú kérdéseket vetnek fel, mint például: "Mi a jó önkormányzat és jó település? Hogyan lehet ezt leírni? Ez a tanulmány jó példát mutat be egy helyi gazdasági fejlesztési kutatásra és sikeres közösségi vezetőkre, megpróbálja bemutatni a helyi hösök tevékenységének fontosságát.

\begin{abstract}
I have chosen this topic to highlight the decisive role of local governments, and in particular the settlement leaders, in forming regional policies. The settlement leadership's way of thinking and their ideas are very important driving forces behind the development of the settlement. Nowadays Settlement Development and Regional Economic Development raise some crucial questions, like: "What is a good local government and a good settlement? How could that be described?" This study explores a best practice for a local economic development research and for successful community leadership, while discussing the importance of local actors.
\end{abstract}

Kulcsszavak: önkormányzat, helyi gazdaságfejlesztés, településfejlesztés

JEL besorolás: R11, H1, H75, P25

LCC: JS39 8500, JS141 163

\section{Bevezetés}

Sokan gondolják már szerencsére azt, hogy a sikeres és jól müködő településvezetés közügy és az is általánosan elfogadható tény, hogy ehhez jól müködö, az erőforrásokat bevonzó és hatékonyan felhasználó helyi gazdaságra van szükség. A helyi gazdaság biztonságos, hosszútávon fenntartható sikeres müködtetése mindannyiunk, akarom mondai a helyi közösség egyik legfontosabb ügye. Ezen kérdések vizsgálata már évek óta foglalkoztatja a Szent István Egyetem Gazdaság- és Társadalomtudományi Karán müködő tudományos műhely kutatóit, mely munkaközösség a Nemzeti Közszolgálati Egyetem kutatóival karöltve pályázati keretben valósítja meg elképzeléseit.

A pályázat jelentősége, hogy állam-centrikus megközelítéssel hozzájárul a biztonság-kultúra fejlesztéséhez, az állam és polgárok biztonság-szemléletének emeléséhez, a vidék versenyképességének növeléséhez. Rendszerbe foglalja és leírja a vidék biztonságának

\footnotetext{
${ }^{1}$ A mủ a KÖFOP-2.1.2-VEKOP-15-2016-00001 azonosítószámú, „A jó kormányzást megalapozó közszolgálatfejlesztés” elnevezésủ kiemelt projekt keretében, a Nemzeti Közszolgálati Egyetem felkérésére készült.
} 
összetevőit, definiálja az állam és a vidékbiztonság kapcsolatrendszerét, jellemzőit, környezetét különös tekintettel a fizikai és a gazdasági biztonsági dimenziók kapcsolatára, melynek eredménye a biztonságos, élhető és versenyképes vidéki élettér. A kutatás alapoz a már meglévő kutatási eredményekre, a közel- és a régmúlt kapcsolódó hazai és nemzetközi történéseinek feldolgozására. A kutatások eredményeként összeálló tudástartalom megjelenik mindkét egyetem oktatásában, valamint az állami és nem állami szereplők képzésében, mint átadható differenciált tudástartalom. A pályázat során jelentős kutatói kapacitási integráció jön létre a két egyetem között.

Ahogy azt a Szilágyi-Boldizsár szerzőpáros megítélésem szerint helyesen megfogalmazza: ”A vidékbiztonsági tudatosság kialakítása eredményeként a polgárok nemcsak, hogy felismerik, értékelik és megértik, hanem kihasználják a vidék és a biztonsági környezet lehetőségeit, de aktív módon befolyásolhatja is azt. A cselekvőképes, tudatos, biztonságtudatos állampolgárként, a törvényi keretek között maguk is hozzájárulhatnak a komplex biztonsághoz mikro- és makroszinten is. A vidékbiztonság valamennyi dimenziójának felismerése és egymással folyamatos kölcsönhatásban lévő dinamikus egységként kezelése új típusú szemléletmódot, felelősségérzetet és gazdasági lehetőséget is hordoz magában. (SzilágyiBoldizsár, 2016)

A kutatás kiinduló pontjaként meghatározásra kerültek a vidékbiztonság különböző pillérei.

- POLITIKAI-KORMÁNYZATI

- FIZIKAI

- GAZDASÁGI

- SZOCIÁLIS-TÁRSADALMI

- KÖRNYEZETI-KÖRNYEZETVÉDELMI

- ÉLELMISZER-ÉLELMEZÉSI

- INFRASTRUKTÚRA

- FENNTARTHATÓSÁG ÉS MEGÚJULÁS

- VIDÉKBIZTONSÁGI ÖNGONDOSKODÁS

A fenti pillérek rendszerbe foglalják mindazokat a tényezőcsoportokat, amelyek meghatározzák a vidékbiztonság egészét. Egyfajta rendszerszemléleti megközelítéssel egy olyan ismerethalmazt tárnak elénk, amelyek átfogóan megmutatják, hogy mely tényezőcsoportokat szükséges a kérdéskör elemzésekor figyelembe venni. Természetesen a jelen tanulmányhoz a gazdasági pillér és a szociális- és társadalmi pillér az, ami közvetlenül kapcsolódik. Ez persze nem jelenti azt - pont a rendszerszemléleti megközelítés okán -, hogy csak ezen pillérekkel kell foglalkoznunk. Akkor tudunk egy jól müködö helyi gazdaságot, vagy sikeres települést kialakítani, hogyha minden egyes tényezőcsoportban megfelelö feltételeket tudunk biztosítani, mivel ezen tényezőcsoportok - nevezetesen pillérek - mindegyike komoly hatást gyakorol a másikra, vagy a többire, ezáltal egyik sem megkerülhető. Természetesen szorosan a gazdasági és a társadalmi kérdéskörök azok, amelyek kapcsolódnak jelen vizsgálatomhoz.

A települések gazdasági, szociális és társadalmi folyamatainak alakításában talán a legnagyobb mozgató erő a helyi vezetés. Ha a vezetési feladatokat ellátó önkormányzati vezetők, polgármesterek, képviselők jól végzik feladataikat, megfelelően átlátják a társadalmi és gazdasági szükségszerüségeket, akkor igazán sikeres és hatékony müködést tudnak elérni. Az általános tapasztalat nem az, hogy ez minden településen jól müködne, mivel nem minden településvezető gondolja azt, hogy akár a gazdasági, akár a társadalmi, szociális kérdésekben neki aktív szereplőnek kellene lennie. Általában a kirótt jogszabályokban rögzített feladatukon túl viszonylag kevés olyan tevékenységet folytatnak, amellyel ezen folyamatokat segíteni 
lehetne. Ez egy nagyon nagy hiányossága a hazai önkormányzati vezetés egészének, pedig a jól müködö települések azok igazán jól müködő települési kormányzást, és hatékony térben való gondolkodást tudnak elérni, és ezáltal tudják támogatni nemcsak a jólétet, hanem a jóllétet adott területi egységen belül. A két fogalom erősen elkülönül egymástól, az első egyfajta gazdasági dimenzióként értelmezhető, a jóllét pedig egy fontos fejlődési kategória, ami egy társadalomi érzést próbál közvetíteni, ahol valós jóllét van, ott mind gazdasági, mind társadalmi mind szociális szempontból kiegyensúlyozott müködés, stabil gazdasági, szociális, társadalmi biztonság valósul meg adott területi egységen belül, természetesen mint ahogy már említettem, ehhez az egyéb biztonsági dimenziók hatékony müködése is szükségszerü.

Arról sem feledkezhetünk meg, amit Oláh Izabella dolgozatában pontosan megfogalmaz, hogy minden település egyedi, "Minden település más és más karakter. Mindegyiknek megvan a maga jellegzetessége, múltja, jelene, mely a jövőjét nagyban meghatározza. Így megfelelő és egységes településcsoportok kialakítása nem lehetséges anélkül, hogy tompítanánk az egyedi jellemvonásokat. Ahhoz tehát, hogy akár csak néhány tényező mentén következtetéseket tudjunk levonni egy kisebb településcsoportra, ismernünk kell a csoportba tartozó minden falut, és fel kell ismernünk a köztük (és más csoportok tagjai között) meghúzódó látható vagy láthatatlan, közvetlen vagy közvetett kapcsolatokat és folyamatokat.” (Oláh, 2017)

Mint ahogy azt már sokan megfogalmazták, minden település egyedi sajátosságokkal rendelkezik, tehát gyakorlatilag két egyforma település nem volt és nem is lesz. Mi következik ebböl? Minden településen sajátos, egyedi megoldásokat kell alkalmaznunk, természetesen ezeknek az összetevőiben lehet különböző mintákat felfedezni, amelyek különböző településeken alkalmazhatók, de mivel nincs két és nem is lesz két egyforma település, ezért mindig valamiféle sajátos, egyedi megoldást kell alkalmazni. Természetesen ez nem jelenti azt, hogy a gazdaságfejlesztés folyamatára nem szükséges egy átgondolt rendszerbe helyezni, és annak megfelelően végig vinni az egész folyamatot ép ellenkezőleg. Erre a cikk későbbi részében javaslatot is teszek, leírva a folyamat lépéseit és ezekhez kötődő feladatokat is részletezni fogom.

Számos alkalommal sokan kimondtuk már, hogy a területi politika, illetve a területfejlesztési politika célja a társadalom és a gazdaság térbeli jellegzetességeinek elemzése, valamint a területi politika fogalomtára egy évtizede egy új fogalommal bővült, ez pedig a területi tőke. Segítségével teljesen egyedi módon jellemezhető egy-egy térség, mivel a különböző területi rendszerek eltérő formában koncentrálják a területi tőke elemeit, amelyek a teljesség igénye nélkül, a földrajzi fekvés, méret, természeti eröforrások, épített örökség, infrastruktúra, társadalmi vagy kapcsolati tőke. „A területi tőke tehát olyan adottságok összessége, amelyek hely- vagy térség specifikusak, s egyben arra orientálják a fejlesztéspolitikát, hogy annak fókuszába a lokális értékek kerüljenek, azok folyamatos megújítására koncentráljanak." (Rechnitzer-Smahó, 2011, Káposzta et al., 2015, Nagyné 2013, Goda-Kassai, 2011, Horváth, 2013) Az egyedi értéket jelentheti a közösség társadalmi aktivitása, helyi gazdasága, infrastruktúrája, adódhat környezeti adottságaiból, valamint a külső anyagi és szellemi javak nyújtotta lehetőségek befogadásának képességéből (Goda-Tóth, 2013, Goda et al, 2013). A települések egyedi értékei igen fontosak, befolyásolják gazdasági sikereik és lakosaik megfelelő életszínvonalának biztosítását (Káposzta, 2016; Ritter et al., 2013).

Mint ahogy azt a Bakos-Bálint szerzőpáros megállapította „Egy közösség, település, térség megfelelő müködéséhez az egészség valamennyi fenti dimenziójára ,szükség van”. A testileg és mentálisan egészséges ember a legfontosabb erőforrás, hiszen biztosítja a munkaerőt, a népesség fennmaradását, a képességek, hagyományok továbbörökítését, az intézmények fenntartását, a jövedelem megtermelését, a közösségszervező eröt.” (Bakos-Bálint, 2015.) 
A települések fejlődésének természetes záloga a gazdasági fejlettségük, amit általában az egy főre jutó GDP-ben (vásárlóerö paritáson) tudunk megjeleníteni, azt is megemlítve, hogy a GDP egy növekedés típusú mutató, tehát a fejlődést kevésbé tudja jellemezni, mivel mint az sokak által elfogadott, a fejlődés egy minőségi változás, a növekedés egy mennyiségi változást tükröz. Ezen sajátosságukat figyelembe véve, az alábbi térképen jól láthatóak azok az elképesztő különbségek, amely a világ országaiban az egy före jutó GDP-ben tetten érhetőek. (1-es ábra)

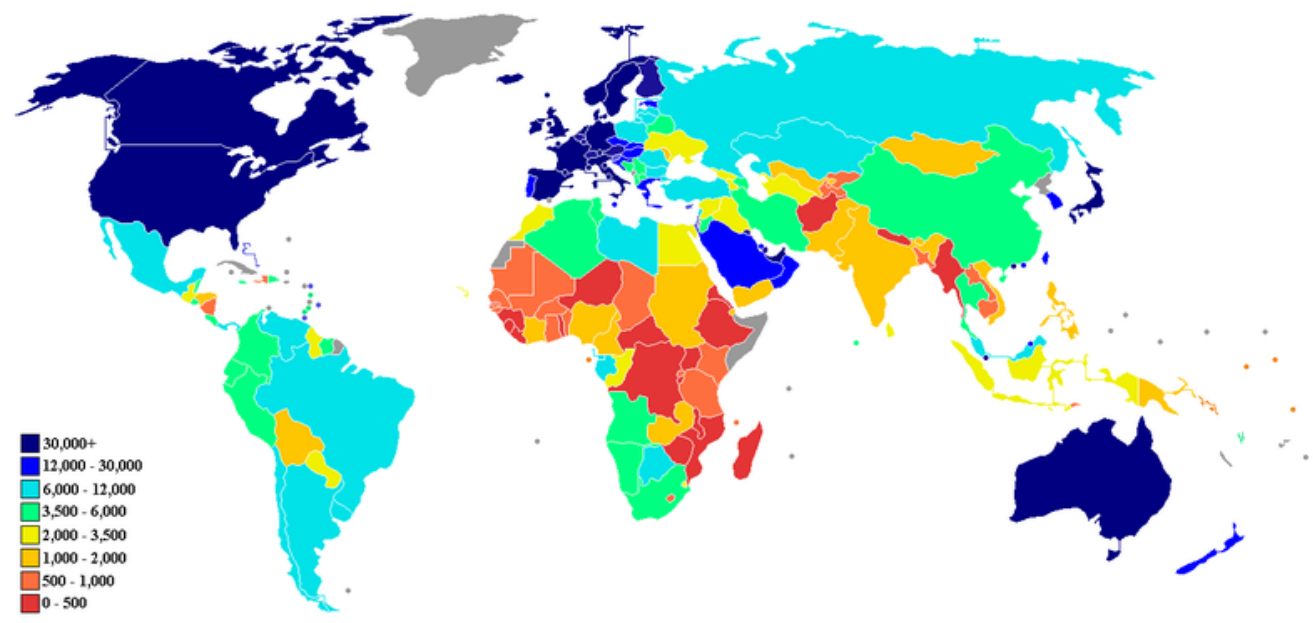

1. ábra: Az egy főre jutó GDP a Föld országaiban

Forrás: IMF, 2015

Akár több százszoros különbség is lehet az egy főre jutó GDP-ben a különböző országok között, figyelembe véve azt is, hogy átlagos GDP-ről van szó, ami olyan különbséget is eltakar, amely az országokon belül még akár ugyanígy több százszoros nagyságrendü lehet. Ezen keretrendszeren belül kell értelmezni azokat a folyamatokat, amelyek egy hatékony gazdaságfejlesztés alapjául szolgálhatnak. Ezen óriási különbségek természetesen komoly kihívásokat jelentenek mind az országok, mind a települések vezetőinek. Arról sem feledkezhetünk meg, hogy különböző méretü településekről kell szólnunk, ezek között is még ennél nagyobb nagyságrendi különbségek lehetnek. Sokan azt mondják, hogy 2050-re a világ népessége már a 9 milliárdot is meg fogja haladni. Ez a népesség nagyobb része az úgynevezett megapoliszokban fog majd összezsúfolódni, és ezen megapoliszokban olyan összetett fejlesztéspolitikát kell üzemeltetni, ami akár különböző országok méretein is messze túlmutatnak, akár 30-40, vagy 50 milliós településekröl kell majd hosszútávon gondoskodni, és ezeknek a müködését megoldani. Mit jelent ez? Talán a legfontosabb az, hogy aki a területfejlesztéssel, városvezetéssel foglalkozik, annak mindig megújuló kihívásokkal kell szembe nézzen és ezen kihívásokra mindig új és újabb válaszokat kell adnia, mivel feltehetőleg a régi válaszokkal nagyon nehéz boldogulni egyik oldalról, másik oldalról akkor lehet egy sikeres várost üzemeltetni ezeken a településeken, ha egy jól átgondolt stratégia mentén a közösség érdekeit képviselve tud megvalósulni a fejlesztés. Természetesen a közösség hatékony és intenzív részvételével, és ez a közösségi részvétel nem csak arra korlátozódik, hogy elmondja melyik irányba nem szeretne menni, természetesen ehhez transzparens és a közösséget integráló fejlesztéspolitikára, kommunikációra van szükség az aktuális városvezetőktől.

\section{Anyag és módszer}

A tanulmány alapvetően három egymástól jó elkülöníthető forrásból építkezik. Egyrészről az intézet munkatársai egy önkormányzati projekt keretében, egy igen gazdag vizsgálati minta 
alapján javaslatot tett egy képzési rendszer megvalósítására az önkormányzatok gazdaságfejlesztési feladatainak támogatására - ez egy majd hatszáz oldalas tanulmány keretében publikálásra is került. Más részről Gerencsér Ilona kutatótársammal már évek óta vizsgálunk különböző sikeres önkormányzatokat és azon belül keressük a sikeresség meghatározó elemeit, legutóbb egy Győr-Moson-Sopron megyei kistelepülés, Csikvánd, közel egy évtizedes fejlődési ívét mutattuk be, másrészt vizsgáltuk a budapesti agglomerációban található Veresegyházat részletesen bemutató elemzéseket. Mivel vizsgálatunk célja a vezetői attitüdök, habitus szerepének, fontosságának kiemelése volt, ezért használtunk fel a számunkra értékesnek tartott, a témához kapcsolódó kutatási eredményeket. A települések helyzetfeltárása egyaránt tartalmazott primer és szekunder vizsgálati elemeket. A primer kutatás során interjú készült a települések polgármestereivel.

A felhasznált háttéranyagoknak a harmadik részét, az az információs bázis adja, ami a Regionális Gazdaságtani és Vidékfejlesztési Intézetben már évtizedek óta felhalmozódott, ami a tér, a települések müködését, a gazdaságfejlesztés hatásait, jó gyakorlatait hivatott csokorba szedni és az Intézeti kollektíva több száz tudományos müvében került publikálásra.

\section{Eredmények}

Több írásmüben jómagam is megfogalmaztam már, hogy hatékony vezetés megfelelő és átgondolt tervezés nélkül nehezen valósítható meg, megkockáztatom csak a jószerencsének köszönhető.

A társadalmi cselekvési kedvet és szerepvállalást valószínüleg legjobban szemlélteti a nonprofit szervezetek száma illetve azok aktivitása. Ennek viszonylatában a jól müködő településekről az mondható el, hogy rendkívül magas társadalmi aktivitást mutatnak, hiszen a non-profit szervezetek száma jelentősen meghaladja pl. Csíkvánd tekintetében a megyei és országos átlagokat. A számuk több mint kétszerese a térségi átlagnak (2. ábra). Az átlagot meghaladó számok, a településvezetővel készült interjúból egyértelműen kiderült, hogy annak a polgármestertől és a képviselő-testülettől származó támogató magatartásnak tulajdonítható, mely a civil szervezetek müködését, aktivitását a messzemenőkig patronálja, ami anyagiakban is kifejezésre jut.

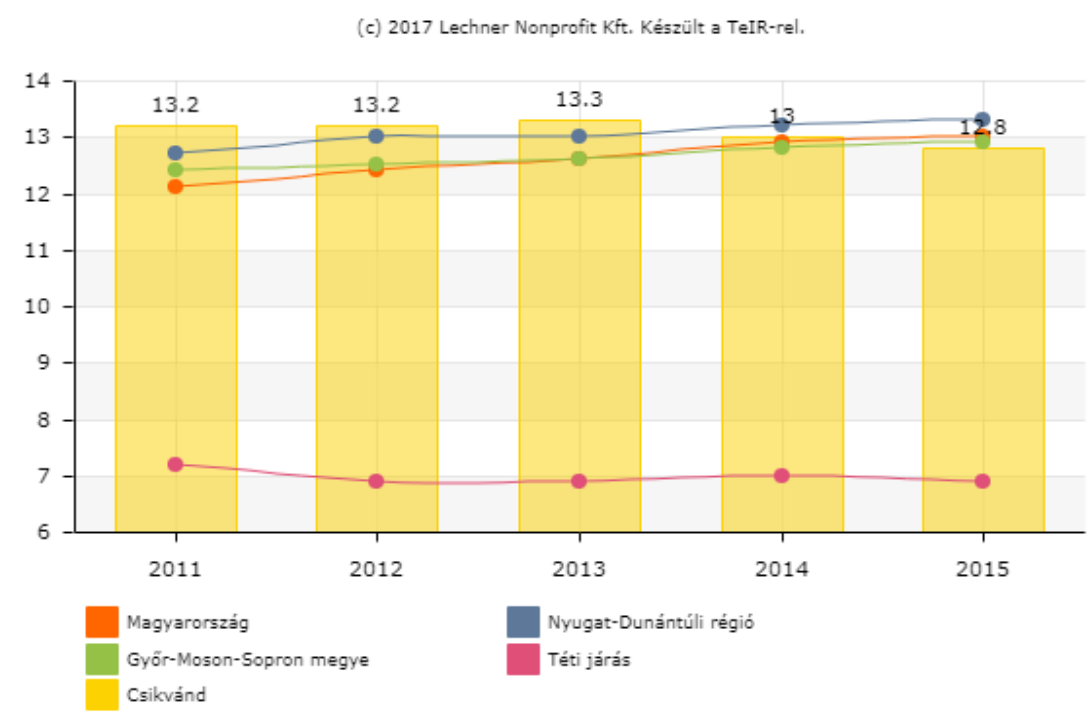

2. ábra Regisztrált nonprofit szervezetek ezer lakosra jutó száma, 2011-től (db) Forrás: TEIR, Helyzet-Tér-Kép, 2017. 
A fejlesztések kapcsán a polgármester úgy fogalmazott: „mi konkrét terveket soha nem készítünk. Hanem az élet, meg a fejlődések visznek bennünket, abba az irányba amerre menni kell. Írott szabályok nincsenek.” (Kozma, 2017) A civil szerveződésekkel, lakossággal viszont folyamatos konzultáció zajlik a felmerült igényekről, fejlesztési elképzelésekről, és amit meg tudnak valósítani, azt együtt valósítják meg. A jó vezetőt meglátásom szerint a közösségével való közös gondolkodás, a közös nyelv, a közösségi érdekek figyelembe vétele külömbözteti meg a többitől. Ö az ötletek egy részének a gazdája, ami mögé aztán támogatóan mellé áll a helyi közösség is.

Sajátos ars poetica-ját a Veresegyházat 1965 óta vezető Pásztor Béla így fogalmazta meg: " $\boldsymbol{A z}$ emberekkel együtt kell élni, ki kell öket szolgálni" (Kovács, 2006)

\section{Integrált gondolkodás}

Az Országos Fejlesztési és Területfejlesztési Koncepció-ban is szerepel véleményem szerit igen jó helyen az alábbi 3-as ábra amely igen markánsan felhívja a figyelmünket a jövőkép, a célok (célrendszer) meghatározásának fontosságára és az integrált, rendszerben való gondolkodásra, mivel az esetleges települési sikerek elérésének ezek is igen fontos meghatározó elemei.

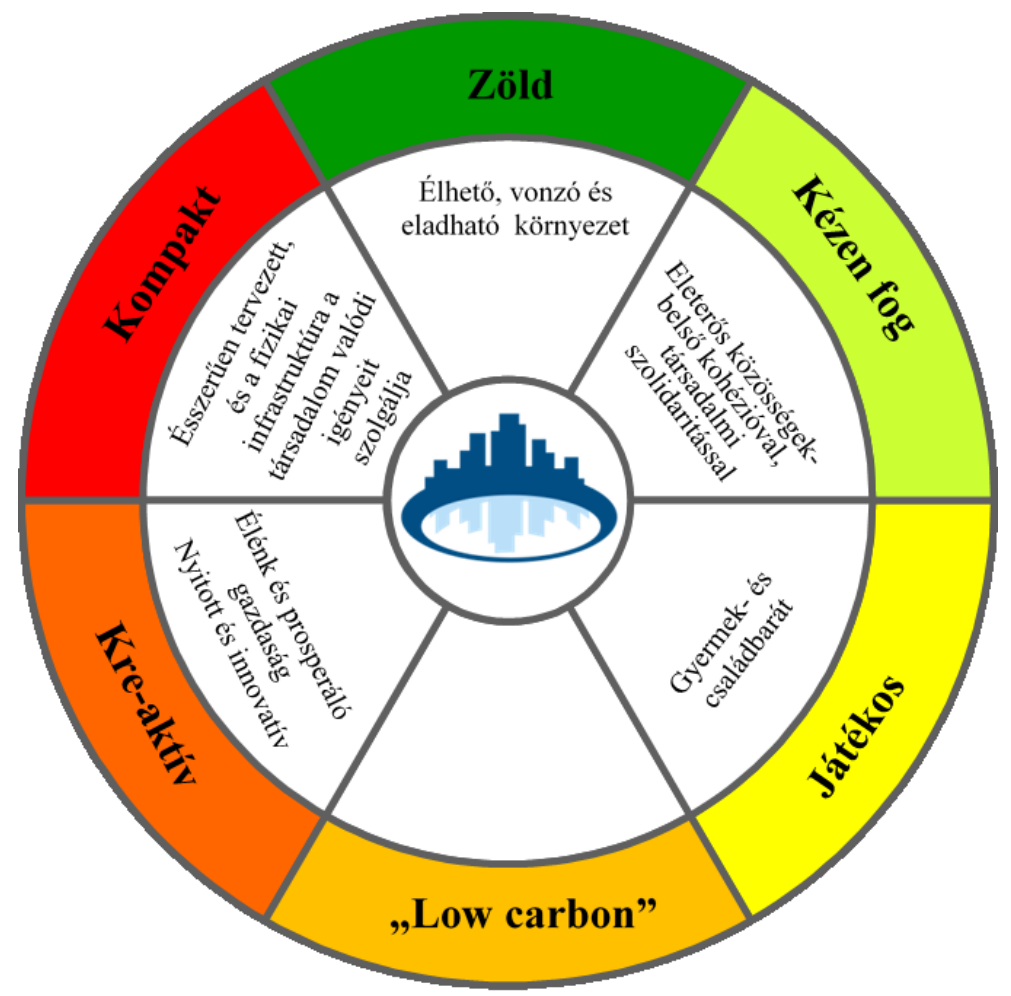

\section{3. ábra Milyen legyen a TELEPÜLÉS/RÉGIÓ?}

\section{Forrás: OFTK 2014}

Részleteiben nem elemezve a fenti ábrát akkor is minden szemlélődő számára egyértelműen világossá kell, hogy váljék - anélkül, hogy meghatároznák, hova szeretnénk eljutni - igen nehéz definiálni az odavezető utat. Bakos (2017) megállapításával egyetértve egy sikeres településnek szüksége van olyan alulról jövő kezdeményezésekre és példaértékü önszerveződő közösségekre, akik hozzá tudnak járulni a helyi gazdaság fejlesztéséhez. A helyi közösségekben meglátása szerint kódolva van az önfenntartás bizonyos foka, amely a megfelelő támogató közeg és a helyi gazdaságfejlesztésben olyan gyakran emlegetett „helyi hősök” közösséget aktivizáló munkája révén felébreszthető és életképesen müködtethető. 


\section{Sikeres önkormányzat jellemzői:}

- Közmegelégedettségre müködteti intézményeit

- Segít a foglalkoztatás megoldásában

- Tiszta és egészséges környezetet teremt

- A helyi érdekek megfogalmazhatók

- Védi a helyi érdekeket

Forrás:(G. Fekete, 2011)

Ha van nyilvánvaló helyi érdek, akkor a döntéshozó is jobban tudja mi a saját feladata! Mindenkire szükség van, aki a közösség erösítéséért tehet (pl.: civilek, egyházak, vállalatok stb.) Mint ahogy azt előző tanulmányunkban is megállapítottuk: "A polgármester tehát nagyon tudatosan, elörelátóan és mindenre kiterjedö figyelemmel irányítja Veresegyházat. Döntései mindig határozottak, legtöbbjük utólag beváltja a hozzá füzött reményeket. A döntések elökészítéséhez a polgármester gyakran kér segítséget, a település rövid- és hosszú távú terveihez szakmai tanulmányokat, elemzéseket készíttet, és az azokban lejegyzetteket figyelembe véve hozza meg döntéseit. Pásztor Béla a lakosság véleményére is kíváncsi, egyegy éppen aktuális témában rendszeresen megkérdezi a veresegyháziak véleményét, a városban gyakoriak a közvélemény-kutatások. Természetesen mindig mindent lehet fejleszteni, a város vezetés hatékonyságát növelni, de azt is meg kell jegyezni, hogy ezt a feladatot majd 60, nem tévedés, majd 60 éve végzi és ezidáig mindig megtörtént az újraválasztása." (Gerencsér-Tóth, 2017)

Visszautalva a biztonsági kérdésekre itt a fejlődést, fejlesztést egy nagyon fontos elem segíti, ami a stabilitásban és az álladóságban érhető tetten és az elmúlt több mint ötven évben a polgármester személyesíti meg. Amellett, hogy ez kellő rugalmasság nélkül nem valósulhatott volna meg, mivel ezt gyökeresen megváltozott keretrendszerekben kellett végrehajtani és ezen rendszerekhez igen sikeresen tudott alkalmazkodni.

A gazdaságfejlesztés tervezése meglátásom szerint három fő szakaszból áll: Helyzetfeltárás, Stratégia kialakítása, Operatív programozás, ezen tervezési szakaszok természetesen több lépésből állnak össze, melyet az alábbi ábra tartalmaz:

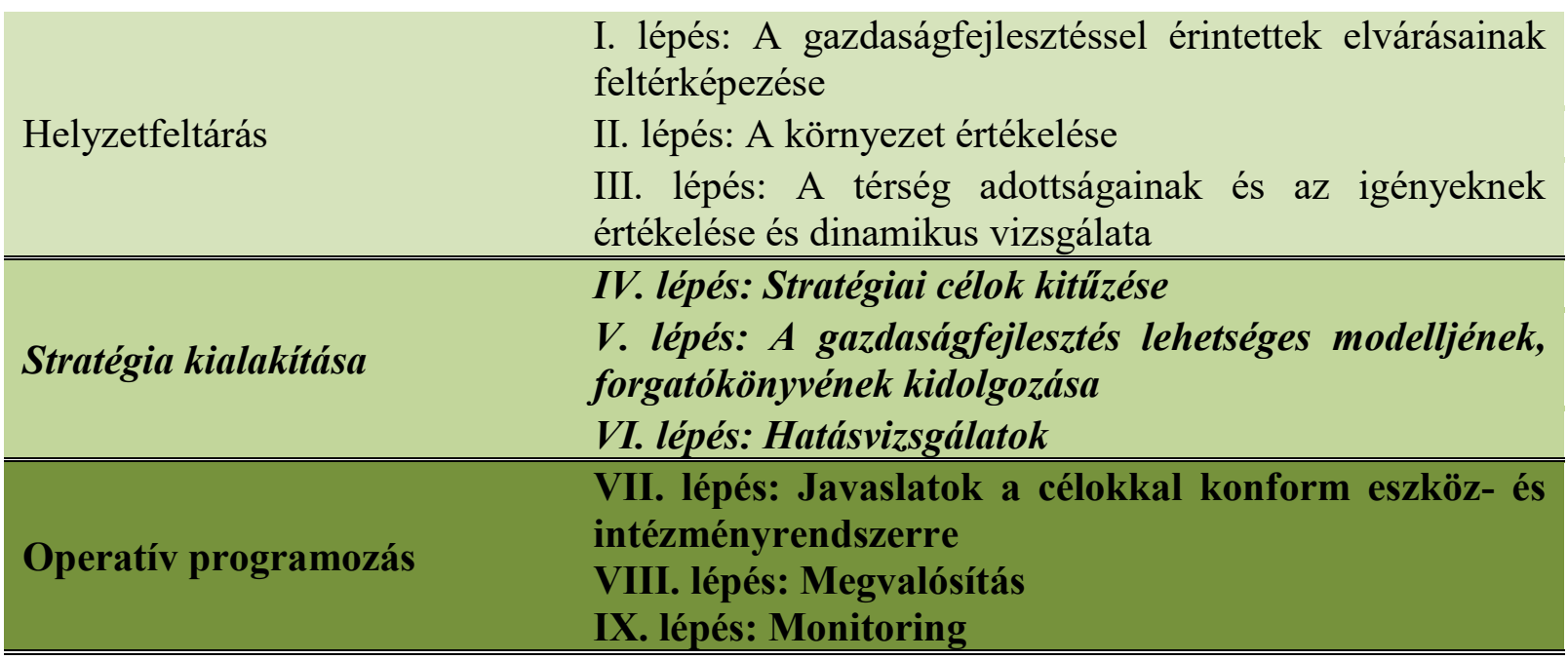

4. ábra A gazdaságfejlesztés tervezési folyamatának föbb lépései (3*3 lépés)

Forrás: Saját szerkesztés

A tervezés általános értelmezése - nevezetesen, hogy az valamilyen kívánatosnak tartott jövőbeli állapot felvázolását, valamint az annak elérését lehetővé tevő út (utak) és feltételek 
(eszközök) meghatározását jelenti - ma is elfogadható. A problémát mindig az okozta, ha a tervezés eredményeként elkészült és gyakran túlzottan részletes tervhez mereven, mint egy megmásíthatatlan cselekvési programhoz ragaszkodtunk. Ez eredményezte, pl. a tervgazdálkodási rendszer torzulásait, hibáit is. Ilyen értelmü tervezésre egy változó gazdaságban valóban nincs szükség.

Más értelemben viszont nem lebecslendő a tervezés jelentősége napjainkban. Ennek elfogadása azonban szemléletváltást igényel. A tervezés célja ugyanis nem egy végleges cselekvési program kidolgozása, hanem - lehetőség szerint minél több „mi lenne, ha” jellegü vizsgálat eredményéböl kiindulva, a korábbi elképzeléseket mindig újra tervezve - folyamatos alkalmazkodás a gazdasági környezet változásaihoz.

\section{Következtetések, javaslatok}

Meglátásom szerint a sikeres település talpraesett vezetők nélkül nem létezhet. Az "igazi" településvezetőkre jellemző a közössége iránti mély és szilárd elkötelezettség, a tenni akarás és az emberek szolgálata, tisztelete a szavakat szó szoros értelemben használva és értve, nem úgy ahogy a választási kampányokban ,puffogtatni” szokták. Továbbá, hogy településük jövőjét, jövőképét illetően határozott elképzelésekkel rendelkeznek, ami akkor elöremutató ha írott formában létezik, azt kellö mértékben ismerik a közösség tagjai és nem csupán elméleti síkon körvonalazódik. (Bár azt meg kell jegyeznem, hogy sokszor, ha az gondolati síkon körvonalazódik már az is örvendetesnek tekinthetö.) Közösségeik építése során a személyes kapcsolataik nagyban segítik a fejlödést, és ez sokszor valós pénztőkére is átváltásra kerül.

Településvezetői pozíciójukat már megelőzte a közigazgatásban eltöltött jó pár év, miközben az élet egyéb területéről is tudást és tapasztalatot szereztek. Rendelkeztek a szükséges kitartással és sok elszántsággal a felmerülő nehézségek idején. Olyan tulajdonságok ezek, melyek egy része az ember veleszületett adottságai közé tartozik. ( Gerencsér-Tóth, 2017)

Az egyéni tulajdonságokon felül fennmaradó részek - melyek a jó településvezetéshez szükséges alapvető információk összességét jelentik - mint ahogy a tanulmányban leírtam, a meglévő településvezetői adottságok, tudások, képességek mind-mind fejleszthetők és készségekké alakítandók egy megfelelöen kialakított (oktatási) rendszer segítségével, hozzásegítve a polgármestereket ahhoz, hogy sikeres településvezetővé váljanak.

\section{Köszönetnyilvánítás}

A mü a KÖFOP-2.1.2-VEKOP-15-2016-00001 azonosítószámú, „A jó kormányzást megalapozó közszolgálat-fejlesztés" elnevezésü kiemelt projekt keretében, a Nemzeti Közszolgálati Egyetem felkérésére készült.

\section{Irodalomjegyzék}

1. Bakos I. (2017): A lokális élelmiszerek fogyasztói megítélése és innovatív értékesítési lehetősége. A Falu, XXXII. évf. 2017. nyár. 5-14 pp.

2. Bakos I. M. - Bálint Cs. (2015): Egészséges (?) Hollókő. In: Nagyné M. M. (szerk.): Acta Regionis Rurum 9. kötet: Faluszemináriumi kutatások - Hollókő. Szent István Egyetemi Kiadó, 92-103.

3. G. Fekete É. (2011): A Nemzeti Vidékstratégia (2014-2020) hangsúlyai a vidéki népesség megélhetése, jövője szemszögéből ， előadás 
https://mtvsz.hu/dynamic/g_fekete eva_videkstrat_a_videki_nepesseg_megelhetese jovoje szemszogebol $201103 \quad 10 . p d f$

4. Gerencsér I., Tóth T. (2017) „Lesz ez még így sem” avagy a településvezetők szerepe helyi fejlesztésekben két település példáján keresztül STUDIA MUNDI ECONOMICA 4:(4) pp. 2-11.

5. Gergely J. (2014): "Településvezetés és szuburbanizáció." Tér és Társadalom 28.4 138-156. DOI: 10.17649/TET.29.2.2717

6. Goda P., Káposzta J, Péli L. (2013): Case study on spider-net enthrophy investigation in rural areas REVIEW ON AGRICULTURE AND RURAL DEVELOPMENT 2:(1) pp. 296-300.

7. Goda P., Kassai Zs. (2011): A 2004-2010 közötti gazdaság - és regionális fejlesztő operatív programok összehasonlító kistérségi vizsgálata. In: Gazdaság és Társadalom 2011/2, pp. 93-110 DOI: 10.21637/GT.2011.2.07

8. Goda P., Tóth T. (2013): Pókháló- entrópia, mint új rendszervizsgálati megközelítés a területi elemzésekben. In: Területi Statisztika, 53 (2) pp. 169-189. DOI: 10.15196/TS560101

9. Horváth E. (2013): Kicsik között a legkisebbek - a törpefalvak sikerességének kulcstényezői, doktori disszertáció, Széchényi István Egyetem, Regionális- és Gazdaságtudományi Doktori Iskola, Győr p.205 DOI: 10.14232/phd.3950

10. Interjú Kozma Tibor Csikvánd Község polgármesterével (2017)

11. Káposzta J.- Ritter K.- Kassai Zs. (2015): Hungarikumok területi jelentőségének vizsgálata, különös tekintettel a pálinkára. In: Tér és Társadalom 29 (4), pp. 139-153. DOI: 10.17649/TET.29.4.2707

12. Káposzta J. (2016): Regionális összefüggések a vidékgazdaság fejlesztésében, In Studia Mundi - Economica Vol. 3. No. 1., Gödöllö, 52-61 pp., DOI: 10.18531/Studia.Mundi.2016.03.01.52-61

13. Kovács, (2006) Interjú Pásztor Béla polgármesterrel, www.origo.hu,

14. Nagyné Molnár M. (2013): Factors of successincase of local society. In: Deturope: Central european journal of tourism and regional development, 5 (3) pp. 63-70. DOI: 10.1057/9780230247017_4

15. OFTK (2014) Az Országgyülés 1/2014. (I. 3.) OGY határozata a Nemzeti Fejlesztés 2030 - Országos Fejlesztési és Területfejlesztési Koncepció, MAGYAR KÖZLÖNY 1. szám MAGYARORSZÁG HIVATALOS LAPJA 2014. január 3., péntek

16. Oláh I. (2017) 1000 fó alatti települések vizsgálata Magyarországon 167 p. Szent István Egyetem Enyedi György Regionális Tudományok Doktori Iskola

17. Oláh I., Áldorfai Gy. Magyarország kistelepüléseinek általános jellemzése, In: Ritter Krisztián (szerk.) Vidékgazdasági tanulmányok. 120 p. Gödöllő: Szent István Egyetemi Kiadó, 2017. pp. 5-14. (ISBN:978-963-269-604-1)

18. Rechnitzer j. Smahó M. ( 2011) Területi politika, Akadémiai Kiadó, 2011

19. Ritter K. - Nagy H. - Tóth T. (2013): Hátrányos helyzetü vidéki térségek és helyi fejlesztési lehetőségeik egy Észak-magyarországi példán keresztül. pp. 224-242. In: Lukovics M. - Savanya P. (szerk.) (2013): Új hangsúlyok a területi fejlődésben. Szeged: JATE Press

20. Szilágyi T., Boldizsár G.: (2016) A biztonságos vidék, mint az állam létfeltétele $P R O$ SCIENTIA RURALIS 1:(4) pp. 24-34.

21. TEIR: Helyzet-Tér-Kép: https://www.teir.hu/helyzet-ter-kep/ (Letöltés: 2017.10.22.) 